\title{
The effect of aerobic training program on cardiopulmonary parameters and oxygen saturation in elite judokas
}

\author{
Tugay YILMAZ, Onder DAGLIOGLU
}

Gaziantep University, School of Physical Education and Sports, Gaziantep, Turkey

Address correspondence to O. Daglioglu, e-mail: daglioglu@hotmail.com

\begin{abstract}
The aim of this study is to examine the effect of aerobic training program on cardiopulmonary parameters and oxygen saturation in elite judokas. Total of 22 male elite judokas, aged between 18 and 25 participated in the study voluntarily. Subjects were randomly divided into two groups as experimental group $(n=11$, age:21.60 \pm 2.06$)$ and control group $(n=11$, age:20.50 \pm 1.77 ). The experimental group was given an aerobic exercise program for 3 days a week for 8 weeks. Before and after the aerobic exercise program, body weight, body mass index (BMI), body fat percentage (BF\%), systolic blood pressure (SBP), diastolic blood pressure (DBP), resting heart rate (RHR), maximal heart rate (HRmax), maximal work rate (WRmax), maximal minute ventilation (VEmax) and maximal oxygen consumption capacity ( $\mathrm{VO}_{2} \mathrm{max}$ ) were measured. Individual oxygen consumption capacities were determined using the Ramp protocol in the gas analysis system. Paired Sample $t$ test was used for intra-group comparison and Independent Sample $t$ test was used for statistical analysis of the data. The level of significance was determined as $\mathrm{p}<0.05$. When the pre-test and post-test results of the aerobic training program applied to the experimental group were compared, $\mathrm{p}<0.05$ significance was found in the experimental group, SBP, DBP, RHR, HRmax, \%BF, $\mathrm{VO}_{2} \max , \mathrm{WRmax}, \mathrm{VEmax}$ and $\mathrm{SpO}_{2}$ values. Significant differences were found between the groups in favor of the experimental group $(\mathrm{p}<0.05)$ for SBP, DBP, RHR, HRmax, WRmax, VEmax, $\mathrm{VO}_{2}$ max and $\mathrm{SpO}_{2}$ values. It can be said that the aerobic training program applied to the judokas has a positive effect on cardiopulmonary parameters and oxygen saturation.
\end{abstract}

Keywords: Aerobic training, Judo, Cardiopulmonary parameters

\section{INTRODUCTION}

Defensive sports have been the interest of researchers as a popular sport. Defensive sports are used by the child or adult for the purpose of selfdefense, body development, fitness and discipline $(7,25)$.

Anthropometric and physiological parameters are of great importance for maximal performance in judo sport $(2,6)$. $\mathrm{VO}_{2} \mathrm{max}$ is considered to be the best value showing cardiovascular performance and aerobic exercise capacity (6).

Cardiopulmonary exercise tests are the most widely used test method to determine exercise performance. In these tests, a gradual stress is applied on the systems with the exercise and the response of the body is evaluated. The parameters used during the evaluation and interpretation of Subjects exercise tests give information about the functions of the systems and how these functions are performed $(18,22)$. In the human body, oxygen is transported in the blood due to large amounts of hemoglobin. Oxygen saturation $\left(\mathrm{SpO}_{2}\right)$ is the ratio of oxygen in the blood to hemoglobin (1). The markers that play a role in the oxygenation of the body due to the determining effect of the oxygen content in the blood on aerobic exercises have become an interesting research topic in terms of sports sciences (12).

The aim of this study was to investigate the effect of aerobic training program on cardiopulmonary parameters and oxygen saturation in elite judoists.

\section{MATERIAL and METHOD}

A total of 22 male judoist volunteers participated in the study between 18-25 years of age in Gaziantep. The subjects were randomly divided 
into two groups as experimental group ( $\mathrm{n}=11$, age: $21.60 \pm 2.06)$ and control group $(n=11$, age: $20.50 \pm 1.77)$. The aerobic exercise program was applied to the experimental group for 3 days during the week for 3 days. Both groups continued their regular judo training. Ethics Committee approval was obtained from Gaziantep University Clinical Research Ethics Committee for the study. The information related to the research was given to the participants. Voluntary form was taken. During the study, they were asked not to take any supplement and to not be able to exercise hard.

\section{Aerobic Training Model}

Athletes were subjected to a run training at $70 \%$ of the target heart rate, 8 weeks, 3 days a week according to the aerobic training method. The intensity of the exercise was determined according to the karvonen method $(12,21)$. As a method of aerobic training, 250m (1min'), 400m (2min'), 650m (3min'), 900m (4min') - 650m (3min'), 400m (2min'), $250 \mathrm{~m}$ (1min') were applied in unit run exercises. Subjects were given a 10 min warm-up exercise before starting the aerobic training, and a $10 \mathrm{~min}$ stretching exercise at the end of the aerobic training.Data Collection

\section{Physical Measurements}

The body weights of the athletes were measured with a scale of $0.1 \mathrm{~kg}$ and the lengths were measured with a digital height measuring device. Subjects participated in the measurements with sportswear (shorts and t-shirts), and bare feet on the scale. The body fat percentage was calculated using the Yuhasz formula, using the skinfold caliper (Holtain, UK) (12).

\section{Cardiopulmonary Exercise Test}

The subjects were subjected to increased cardiopulmonary exercise test (Ramp protocol) on RESULTS

Table 1 provides a comparison of the pre-test and post-test results of the data obtained after the aerobic training program applied to the experimental group. The experimental group, SBP, DBP, RHR, HRmax, BF\%, $\mathrm{VO}_{2}$ max, WRmax, VEmax and $\mathrm{SpO}_{2}$ values were found to be significant $(p<0.05)$. The body weight and BMI of the experimental group did not show any significance $(\mathrm{p}>0.05)$. the bicycle ergometer (Mec Pft Systems Ergo). The protocol increased 3 minutes of rest, 3 no-load pedals (warm-up) and 25 watts per minute. Pedaling rate was kept constant at approximately 60-70 rpm. The test was continued until the subjects could not tolerate the increased load. As soon as the test was completed, the pedal load was reduced to 25 watts and pedaled for another 3 minutes and the test was completed (3). WRmax, VEmax, HRmax and $\mathrm{VO}_{2} \mathrm{max}$ were measured with this test.

\section{Oxygen Saturation $\left(\mathrm{SpO}_{2}\right)$}

Oxygen saturation was measured by attaching the Pulse Oximeter to the fingertip while the subject was seated and the right hand side on the desk was facing up. The value that appears on the digital display has been saved.

\section{SBP and DBP Measurement:}

Systolic blood pressure, Diastolic blood pressure and resting heart rate measurement were measured digitally. (Omron, M6 Comfort, Omrom Healthcare Co., Ltd. Kyoto, Japan). Two measurements were made with an interval of 1 minute and means of them were recorded.

\section{Statistical Analysis}

The Statistical analysis of this study was performed with the help of SPSS statistics program (SPSS for Windows, version 20.0, SPSS Inc. Chicago, Illinois, USA). Shapiro-Wilk test was applied to determine whether the data were normally distributed and homogeneous. Independent Samples $\mathrm{T}$ Test was applied for the difference between experimental group and control group. Paired Samples T Test was used to compare the groups. Statistical results were analyzed at $p<0.05$ significance levels. 
Table 1. Pre-test and post-test analysis results of the experimental group

\begin{tabular}{|c|c|c|c|c|c|}
\hline \multirow{2}{*}{ Variable } & Pre-test & Post-test & \multirow{2}{*}{$\mathrm{df}$} & \multirow{2}{*}{$\mathrm{t}$} & \multirow{2}{*}{$\mathrm{p}$} \\
\hline & Mean \pm SD & Mean \pm SD & & & \\
\hline Age (year) & $21.16 \pm 3.45$ & $21.16 \pm 3.45$ & - & - & - \\
\hline Height $(\mathrm{cm})$ & $173.72 \pm 5.16$ & $173.72 \pm 5.16$ & - & - & - \\
\hline Weight (kg) & $71.54 \pm 3.22$ & $71.11 \pm 1.12$ & 10 & 0.256 & 0.711 \\
\hline BMI $\left(\mathrm{kg} / \mathrm{m}^{2}\right)$ & $22.16 \pm 1.12$ & $22.09 \pm 1.24$ & 10 & 0.211 & 0.851 \\
\hline $\mathrm{BFP}(\%)$ & $10.44 \pm 3.21$ & $9.69 \pm 1.73$ & 10 & 3.511 & $0.001^{*}$ \\
\hline $\mathrm{SBP}(\mathrm{mmHg})$ & $105.12 \pm 4.12$ & $102.24 \pm 3.85$ & 10 & 4.256 & 0.001* \\
\hline $\mathrm{DBP}(\mathrm{mmHg})$ & $69.12 \pm 4.12$ & $67.52 \pm 3.16$ & 10 & 3.412 & 0.001* \\
\hline RHR (atım/dk) & $70.22 \pm 2.46$ & $68.12 \pm 2.56$ & 10 & 9.115 & $0.001^{*}$ \\
\hline HRmax(atım/dk) & $187.42 \pm 4.22$ & $194.12 \pm 2.47$ & 10 & -8.356 & $0.001^{*}$ \\
\hline WRmax (W) & $247.26 \pm 15.16$ & $256.12 \pm 15.22$ & 10 & -5.655 & $0.012^{*}$ \\
\hline VEmax (1/min) & $132.16 \pm 9.14$ & $135.26 \pm 8.24$ & 10 & -4.122 & $0.004^{*}$ \\
\hline $\mathrm{VO}_{2} \max (\mathrm{ml} / \mathrm{kg} / \mathrm{dk})$ & $45.56 \pm 3.06$ & $53.12 \pm 1.71$ & 10 & -7.211 & 0.001* \\
\hline $\mathrm{SpO}_{2}(\%)$ & $96.7 \pm 0.12$ & $97.8 \pm 1.52$ & 10 & -3.127 & 0.001* \\
\hline
\end{tabular}

${ }^{*} \mathrm{p}<0.05$

Table 2. Pre-test and post-test analysis results of the control group

\begin{tabular}{|c|c|c|c|c|c|}
\hline \multirow{2}{*}{ Variable } & Pre-test & Post-test & \multirow{2}{*}{$\mathrm{df}$} & \multirow{2}{*}{$\mathrm{t}$} & \multirow[b]{2}{*}{$\mathrm{p}$} \\
\hline & Mean \pm SD & Mean \pm SD & & & \\
\hline Age (year) & $21.72 \pm 2.11$ & $21.72 \pm 2.11$ & - & - & - \\
\hline Height $(\mathrm{cm})$ & $175.09 \pm 2.16$ & $175.09 \pm 2.16$ & - & - & - \\
\hline Weight (kg) & $74.17 \pm 2.95$ & $75.12 \pm 2.52$ & 10 & -0.623 & 0.696 \\
\hline BMI $\left(\mathrm{kg} / \mathrm{m}^{2}\right)$ & $22.74 \pm 2.08$ & $22.96 \pm 1.04$ & 10 & -0.254 & 0.653 \\
\hline BFP (\%) & $11.74 \pm 1.56$ & $10.57 \pm 3.41$ & 10 & 0.623 & $0.041^{*}$ \\
\hline $\mathrm{SBP}(\mathrm{mmHg})$ & $112.00 \pm 8.09$ & $110.91 \pm 6.87$ & 10 & 2.269 & $0.032^{*}$ \\
\hline DBP (mmHg) & $71.12 \pm 2.34$ & $70.08 \pm 1.60$ & 10 & 0.185 & $0.002^{*}$ \\
\hline RHR (atım/dk) & $70.69 \pm 1.42$ & $69.50 \pm 1.22$ & 10 & 1.124 & 0.025 \\
\hline HRmax(atım/dk) & $185.66 \pm 2.46$ & $186.00 \pm 2.21$ & 10 & -1.478 & 0.363 \\
\hline WRmax $(W)$ & $239.54 \pm 10.45$ & $243.08 \pm 9.12$ & 10 & -1.690 & 0.072 \\
\hline VEmax (1/min) & $130.33 \pm 5.12$ & $131.52 \pm 4.21$ & 10 & -0.296 & 0.452 \\
\hline $\mathrm{VO}_{2} \max (\mathrm{ml} / \mathrm{kg} / \mathrm{dk})$ & $44.22 \pm 1.56$ & $45.32 \pm 1.69$ & 10 & -2.789 & 0.151 \\
\hline $\mathrm{SpO}_{2}(\%)$ & $97.11 \pm 0.89$ & $97.52 \pm 1.12$ & 10 & -2.175 & 0.322 \\
\hline
\end{tabular}

Table 2 provides a comparison of the pre-test and post-test results of the control group. Significant values were found in the control group, RHR, SBP,

Table 3. Comparison of experimental and control groups

\begin{tabular}{|c|c|c|c|c|c|}
\hline \multirow[t]{2}{*}{ Variable } & $\begin{array}{c}\text { Experimental Group } \\
\text { Difference }\end{array}$ & $\begin{array}{c}\text { Control Group } \\
\text { Difference }\end{array}$ & \multirow[t]{2}{*}{$\mathrm{df}$} & \multirow[t]{2}{*}{$t$} & \multirow[t]{2}{*}{$\mathrm{p}$} \\
\hline & Mean \pm SD & Mean \pm SD & & & \\
\hline Weight (kg) & $0.43 \pm 1.18$ & $-0.95 \pm 0.44$ & 20 & 2.136 & 0.213 \\
\hline BMI $\left(\mathrm{kg} / \mathrm{m}^{2}\right)$ & $0.07 \pm 0.52$ & $-0.22 \pm 0.41$ & 20 & 1.356 & 0.512 \\
\hline $\mathrm{BFP}(\%)$ & $0.75 \pm 0.92$ & $1.17 \pm 1.05$ & 20 & 2.162 & 0.057 \\
\hline SBP (mmHg) & $2.88 \pm 3.52$ & $1.09 \pm 1.56$ & 20 & 2.542 & $0.032^{*}$ \\
\hline $\mathrm{DBP}(\mathrm{mmHg})$ & $1.60 \pm 0.97$ & $1.04 \pm 1.03$ & 20 & 1.221 & $0.044^{*}$ \\
\hline RHR (atım/dk) & $2.10 \pm 0.63$ & $1.19 \pm 1.02$ & 20 & 2.114 & $0.001^{*}$ \\
\hline HRmax(atım/dk) & $-6.70 \pm 2.45$ & $-0.34 \pm 1.19$ & 20 & -5.412 & $0.001^{*}$ \\
\hline WRmax (W) & $-8.86 \pm 3.63$ & $-3.54 \pm 3.21$ & 20 & -3.863 & $0.001^{*}$ \\
\hline VEmax (1/min) & $-3.10 \pm 1.64$ & $-1.19 \pm 1.85$ & 20 & -2.157 & $0.003^{*}$ \\
\hline $\mathrm{VO}_{2} \max (\mathrm{ml} / \mathrm{kg} / \mathrm{dk})$ & $-7.56 \pm 2.11$ & $-1.10 \pm 1.58$ & 20 & -7.765 & $0.001^{*}$ \\
\hline $\mathrm{SpO}_{2}(\%)$ & $-1.10 \pm 0.59$ & $-0.41 \pm 1.14$ & 20 & -2.245 & $0.042^{*}$ \\
\hline
\end{tabular}

$$
{ }^{*} \mathrm{p}<0.05
$$

Table 3 presents the comparison of measurement results after cardiopulmonary exercise test applied to the experimental and control groups. Among the groups, significant differences were
$\mathrm{DBP}$ and $\mathrm{BF} \%$ values of $\mathrm{p}<0.05$. There was no significant difference in the other data of the control group ( $p>0.05)$.

found in SBP, DBP, RHR, HRmax, WRmax, VEmax, $\mathrm{VO}_{2}$ max and $\mathrm{SpO}_{2}$ values in favor of the experimental group $(p<0.05)$. There was no 
significant difference in Weight, $\mathrm{BMI}$ and $\mathrm{BF} \%$

\section{DISCUSSION}

\section{Cardiopulmonary Parameters}

Cardiopulmonary exercise tests allow for individual's strength status and the solution of problems according to organism's response to the stress applied to the individuals in changing workloads. At the same time, they are important in terms of meeting increased energy need and continuing to the exercise during exercise (24).

$\mathrm{VO}_{2} \mathrm{max}$ has an important role in long-term physical activities (19). It has been reported that breathing is accelerated during the aerobic exercise, and the heart starts to be stronger and faster (4, 23).VEmax values are known to increase with exercise (16). However, in subjects with regular training, the increase in VE is less during exercise than sedentary.

In our study, $\mathrm{VO}_{2}$ max, VEmax, WRmax, SBP, DBP, RHR and HRmax values were found to be significant at $\mathrm{p}<0.05$ level after the aerobic training program of the experimental group. RHR SBP and DBP values of the control group were significant at $p<0.05$ level. No other significance was found in the other data of the control group ( $p>0.05)$. Among the groups, VO2max, VEmax, WRmax, SBP, DBP, RHR and HRmax values were found to be significant in favor of the experimental group $(\mathrm{p}<0.05)$

Ingham et al. (2007) Olympic and club-level rowing athletes examined the amount of oxygen consumption in their work, the club athletes $\mathrm{VO}_{2}$ max value of $55.6 \pm 1.2$, the Olympic athletes have determined the $\mathrm{VO}_{2}$ max value of $61.1 \pm 0.6 \mathrm{ml} / \mathrm{kg} / \mathrm{min}$ (14). In a study on badminton players, $\mathrm{VO}_{2}$ max values were $61.8 \pm 5.9$ in males and $50.3 \pm 4.1$ $\mathrm{ml} / \mathrm{kg} / \mathrm{min}$ in females (11). In a study conducted on footballers, after 8 weeks of aerobic exercise program, WRmax, VEmax and $\mathrm{VO}_{2}$ max parameters were found statistically significant in experimental group (13). It is known that VEmax value increases with training and exercises (16). However, VE increase is lower in the individuals who exercise regularly than ones living sedentarily at rest and during low intensity exercise. In another study, a statistically significant difference was found between BMI, DBP, $\mathrm{VO}_{2}$ max and WRmax values after the cardiopulmonary exercise test applied to the experimental and control groups. VEmax values were increased in favor of the experimental group (10).
In our study, the experimental group reached a larger workload (WRmax) and increased $\mathrm{VO}_{2}$ max in the cardiopulmonary exercise test performed after the aerobic exercise program according to the control group. Therefore, it can be said that the $\mathrm{VO}_{2}$ max value of the experimental group is higher than the control group after the aerobic exercise program. It can be said that VEmax is higher in favor of the experimental group and that the volume of breath is increased in the experimental group.

As the body starts to respond to heart rate, stroke volume and blood pressure increase. As the exercise continues, the heart rate, blood pressure and heart rate are fixed, the number of respiration increases (4).

In a study conducted, 8-week submaximal aerobic exercise applied to young males found a significant decrease in RHR values (9). In another study on handball players, a significant decrease in RHR values was obtained as a result of the aerobic training program (15).

In our study, there were significant decreases in the number of heart rates in the experimental group as a result of aerobic exercise. It can be said that this condition is due to hypertrophy in the left ventricle of the heart. Significance was not found in the control group. The results of our study are parallel with the literature.

Stewart et al. (2005) had the subjects make aerobic exercise and obtained significance SBP and DBP values in favor of the post- test at the end of program in their study (20). In a study conducted on swimmers, there was a significant decrease in DBP values (10). There are many studies that found a decrease in SBP and DBP values after training and aerobic exercise $(5,9,13)$.

In our study, as a result of aerobic exercise in the experimental group, significant decreases were obtained in SBP and DBP values. This result can be said to increase the pressure in the blood vessels during exercise.

\section{Oxygen Saturation}

In the human body, oxygen is transported in the blood due to large amounts of hemoglobin. Oxygen saturation $\left(\mathrm{SpO}_{2}\right)$ is the ratio of oxygen in the body to hemoglobin in the body (1). 
In a study conducted on young male individuals, a significant increase was found in $\mathrm{SpO}_{2}$ values after 8 weeks of submaximal aerobic exercise (9). In another study, it was determined that shortterm exercise decreased oxygen saturation in football players (8). In a study to investigate the effect of aerobic training on $\mathrm{SpO}_{2}$, an increase of $97.85 \pm 0.88 \%$ was obtained from $97.23 \pm 0.93 \%$ of the $\mathrm{SpO}_{2}$ values of the experimental group (17). In our study, there was a significant increase in $\mathrm{SpO}_{2}$ values of the experimental group after 8 weeks of aerobic training program. We think that the increase in $\mathrm{SpO}_{2}$ values is due to the increase in blood hemoglobin level due to the effect of training as a result of the development of respiratory muscles.

\section{CONCLUSION}

As a result, it can be said that 8-week aerobic training program applied to elite judokas affects the cardiopulmonary parameters and oxygen saturation positively. It is suggested that aerobic exercise programs should be included in the annual training planning regularly and planned, together with judo training for the development of high performance, cardiopulmonary parameters and oxygen saturation in judo training.

\section{REFERENCE}

1. Acartürk E. KOAH Hastalarındaki Oksijen Satürasyonunun Pulse Oksimetre ile Tesbitinin Arter Kan Gazı Tetkiki ile Korelasyonu ve $\mathrm{Bu}$ Korelasyonu Etkileyen Faktörler. Uzmanlık Tezi, Süreyyapaşa Göğüs Kalp ve Damar Hastalıkları Eğitim ve Araştırma Hastanesi, İstanbul, 2009.

2. Ağaoğlu SA, İmamoğlu O, Kishalı NF. Türk Erkek Milli Judo Takım Sporcularının Belirli Fizyolojik ve Antropometrik Özelliklerinin İncelenmesi. Atatürk Üniversitesi Beden Eğitimi ve Spor Bilimleri Dergisi, 2001; 1:59-57.

3. American Thoracic Society American Collge of Chest Physicians. Am J Respir Crit Care Med. 2003; 167, 211-277.

4. Ardıç F. Egzersiz reçetesi. Türkiye Fiziksel Tıp ve Rehabilitasyon Dergisi, 2014; 60, 1-8.

5. Blumenthal JA, Sherwood A, Gullette ECD, Babyak MA, Waugh R, Georgiades A, Craidhead LW, Tweedy D, Feinglos M, Appelbaum M, Hayano J, Hinderliter A. Exercise and weight loss reduce blood pressure in men and women with mild hypertension. Arch Intern Med, 2000; 160(13):1947-58.

6. Claessens A, Beunen G, Wellens R, Geldof G. Somatotype and Body Structure of World Top Judoists, J Sports Med Phys Fitness. 1987;27:105- 112.

7. Cox JC. Traditional Asian martial arts training: a review. Quest, 1993; 45;366-388.

8. Daglioglu O, Mendes B, Bostanci O, Ozdal M, Demir T. The Effect of Short-Term Exercise on Oxygen Saturation in Soccer Players. Australian Journal of Basic and Applied Sciences, 2013; 7(10): 446-449.

9. Daglioglu O. (a). The effect of 8-week submaximal aerobic exercise on cardiovascular parameters and body composition in young men. International Journal of Acdemic Reseach, 2013; 5(4), 210-216.

10. Daglioglu O. (b). The effect of gradually increasing exercise on oxygen consumption and lactate levels in swimmers. Annals of Biological Research, 2013; 4(10):96-102.

11. Faude O, Meyer T, Rosenberger F, Fries M, Huber G, Kindermann W. Physiological characteristics of badminton match play. European j. Applied Physiology, 2007; 100:4, 479485.

12. Fox Bowers Foss. Beden Eğitimi ve Sporun Fizyolojik Temelleri, Ankara: BağırganYayınevi, 1999.

13. Gücenmez E, Dağlıoğlu Ö, Dağlıoğlu T. The Effect of Aerobic Exercise on Oxygen Consumption Capacities and Body Composition in Football Players, Atabesbd, 2017; 19(4):136147.

14. Ingham SA, Carter H, Whyte GP, Doust JH. Comparison of the oxygen uptake kinetics of club and olympic champion rowers. Medicine and science in Sports and Exercise, 2007; (5):865-871.

15. Koç H. Aerobik antrenman programının erkek hentbolcularda bazı dolaşım ve solunum parametrelerine etkisi. Selçuk Üniversitesi Beden Eğitimi ve Spor Bilim Dergisi, 2010; 12(3):185-190.

16. McArdle WD, Katch FI, Katch VL. Exercise Physiology. 3 rd ed. Lea \& Febiger, Philadelphia, 1991:278-284.

17. Özdal M, Dağlıŏglu Ö, Demir T, Özkul N. Aerobik Antrenmanın Arteriyel Hemoglobin Oksijen Satürasyonu Üzerine Etkisi, Spor ve Performans Araştırmaları Dergisi, 2013; 5(1):27-34.

18. Pichurko BM. Exercising your patient: which test(s) and when? Respir Care, 2012; 57: 100-10.

19. Saltin, B. Training for anaerobic and aerobic power. In McArdle WD, Katch FI, Katch VL, (eds.). Exercise physiology Energy, Nutrition \& Human Performance (6th ed.) Baltimore: Lippincott Williams \& Wilkins, 2007: 469-508.

20. Stewart KJ, Bacher AC, Turner KL, Fleg JL, Hess PS, Shapiro EP, Tayback M, Ouyang P. Effect of exercise on blood pressure in older persons: a randomized controlled trial. Arch Intern Med, 2005; 165(6): 756-62.

21. Tamer K. Measurement and Evaluation of PhysicalPhysiological Performance in Sports, Bağırgan Publishing, Ankara, 2000.

22. Ulubay G, Oner Eyüboğlu F. Cardiopulmonary exercise testing. Tuberk Toraks, 2006; 54: 90-8.

23. Vargo L, Sanderson S. Compression stockings and aerobic exercise: A Meta-Analysis. Sport and art, 2014; 2(4), p. 68-73.

24. Wasserman K, Hansen JE, Sue DY, Stringer WW, Whipp BJ. Principles of Exercise Testing and Interpretation. 4th ed. Philadelphia, Pa: Lippincott Williams \& Wilkins, 2004.

25. Zetaruk MN, Violan MA, Zarakowski D, Micheli LJ. Karate Injuries in children and adolescents, Accident Analysis and Prevention, 2000; (32), 421-425. 